\title{
Procyclidine Hydrochloride
}

National Cancer Institute

\section{Source}

National Cancer Institute. Procyclidine Hydrochloride. NCI Thesaurus. Code C47689.

The hydrochloride salt form of procyclidine, with anticholinergic properties. Procyclidine hydrochloride competitively binds to striatal cholinergic receptors, thereby diminishing acetylcholine activity and ultimately reducing the frequency and severity of akinesia, rigidity, and tremor associated with uncontrollable body movements. In addition, this agent may block the re-uptake of dopamine by nerve terminals, thereby increasing dopamine activity. 